\title{
GMR
}

\section{Selecting black-spot resistant papaya genotypes derived from backcrossing and hybrids}

\author{
T.P.S. Poltronieri ${ }^{1}$, S.F. Silveira ${ }^{1}$, M. Vivas ${ }^{2}$, R. Santa Catarina ${ }^{3}$, \\ D.F.M. Cortes ${ }^{3}$, A.O.N. Azevedo ${ }^{3}$ and M.G. Pereira ${ }^{3}$ \\ ${ }^{1}$ Laboratório de Entomologia e Fitopatologia, \\ Universidade Estadual do Norte Fluminense Darcy Ribeiro, \\ Campos dos Goytacazes, RJ, Brasil \\ ${ }^{2}$ Laboratório de Engenharia Agrícola, \\ Universidade Estadual do Norte Fluminense Darcy Ribeiro, \\ Campos dos Goytacazes, RJ, Brasil \\ ${ }^{3}$ Laboratório de Melhoramento Genético Vegetal, \\ Universidade Estadual do Norte Fluminense Darcy Ribeiro, \\ Campos dos Goytacazes, RJ, Brasil \\ Corresponding author: T.P.S. Poltronieri \\ E-mail: tathianne_pastana@hotmail.com
}

Genet. Mol. Res. 16 (1): gmr16019401

Received October 4, 2016

Accepted December 5, 2016

Published February 23, 2017

DOI http://dx.doi.org/10.4238/gmr16019401

Copyright $(2017$ The Authors. This is an open-access article distributed under the terms of the Creative Commons Attribution ShareAlike (CC BY-SA) 4.0 License.

ABSTRACT. Papaya crop is important to Brazilian agribusiness.
However, the expansion of papaya cultivation in the country is affected
by the absence of commercial cultivars presenting good disease
resistance. The black-spot caused by the fungus Asperisporium caricae
is the most damaging foliar disease affecting Brazilian papaya crops.
The use of genetically resistant cultivars is a promising strategy to
reduce the dependence of papaya crops on fungicides. A field split-plot
experiment was carried out in the municipality of Linhares, Espírito
Santo State, and included 20 hybrids derived from the cross between 14
superior lines and four elite genotypes ('SS72/12', 'SEKATI', 'JS/12'
and ' $41 / 7$ '), two commercial cultivars ('Golden' and 'Tainung 01 '),

Genetics and Molecular Research 16 (1): gmr16019401 
and the superior line ' $36 / 7$ ', which were evaluated for resistance to black-spot in the fruits and leaves. The treatments were arranged in a randomized block design with six repetitions of three plants per plot. The incidence and severity of black spot in the fruits and leaves were evaluated at three different times in the 2015-2016 crop season. Lines 4, 9, 21, and the parent SEKATI were notable for their capacity to reduce disease severity in the leaves and fruits. Lines 1, 2, 9, 16, and 19, and the parents 'SEKATI' and 'SS-72/12' had reduced disease incidence in their fruits. The most resistant hybrids 'SS-72/12 X 4', 'SS-72/12 $X$ 6', 'SEKATI X 1', 'SEKATI X 2', 'SEKATI X 6', 'SEKATI X 9', and 'SEKATI X 20' presented negative heterosis values for improved black-spot resistance. The current study allowed the selection of blackspot resistant genotypes and hybrids, which presented a significantly reduced disease index in the field.

Key words: Carica papaya; Asperisporium caricae; Hybridization; Heterosis; Disease resistance

\section{INTRODUCTION}

Papaya (Carica papaya L.) crop is commercially grown in Brazil, mainly in Bahia and Espírito Santo states. These states produce 718,726 and 404,720 tons of fruit per year, respectively. Together, they accounted for 71\% of Brazil's total papaya production in 2013. In the same year, Brazil was the second largest papaya producer in the world, with a total production of 1.6 million tons of fruit, which corresponded to $12.6 \%$ of the world production (IBGE, 2014; Reetz et al., 2015).

The demand for more adapted papaya cultivars to meet the requirements of both national and international markets is currently a core issue for papaya plant cultivation in the main producing areas in Brazil. The national papaya markets prefer cultivars that present larger fruits (the Formosa group) whereas the international markets prefer cultivars that present smaller fruits (the Solo group). Therefore, breeding programs using hybridization techniques (Marin et al., 2006) have increased the genetic variability of this crop in order to generate materials with enhanced agronomic features, as well as higher levels of disease resistance.

Marin et al. (2006) studied the general and specific combining ability of genotypes from the 'Solo' and 'Formosa' groups. They found that the 'Cariflora' genotype shows excellent general and specific abilities to combine several agronomic features when crossed with 'Solo' group cultivars. However, since such a genotype is a dioecious material, it is not possible to use it in breeding programs due to the impossibility of self-fertilization and the development of inbred lines. Silva et al. (2007a) attempted to convert the sex of the 'Cariflora' genotype, from dioecious to the gynoecious - andromonoecious stage, by means of random amplified polymorphic DNA marker-assisted introgression of the M2 allele. BC1 and $\mathrm{BC} 2$ populations derived from the crossing between 'Cariflora' and 'Sunrise Solo 783' were obtained, and plants showing high similarity to the recurrent parent ('Carifora') were selected. Ramos et al. (2012) assessed the genetic distance between populations derived from three backcrossing generations $(\mathrm{BC} 1, \mathrm{BC} 2$, and $\mathrm{BC} 3)$ in order to select superior genotypes and to advance generations through self-fertilization, and to analyze the efficiency of morpho-

Genetics and Molecular Research 16 (1): gmr16019401 
agronomic and molecular data at estimating genetic diversity and correctly distinguishing the studied progenies. The assessed backcrossing populations have shown agronomically superior genotypes. However, little is known about the resistance of these materials to the main diseases affecting papaya crops, or about their behavior per se or in crossings. Nevertheless, it is believed that these populations have potential disease-resistance that can be explored for use in disease control and in papaya breeding programs. Vivas et al. (2015) assessed genotypes from the UENF/CALIMAN germplasm bank and found that the 'Cariflora' genotype showed low black-spot [Asperisporium caricae (Speg.) Maubl.] severity levels in the leaves and fruits. Black spot is one of the most important leaf diseases affecting papaya crops. Some studies have used heterosis aiming to increase disease resistance (Hafsah et al., 2007; Vivas et al., 2012b; 2014), which also allows significant genetic gains concerning morpho-agronomic features to be achieved. This is also accompanied by improved resistance to other diseases such as anthracnose (Colletotrichum gloeosporioides), black-spot (Asperisporium caricae), and phoma-spot (Phoma caricae-papayae) (Vivas et al., 2014).

Black-spot is the most important leaf disease affecting papaya cultivations, since the infection occurs in the leaves, and it leads to defoliation and loss of the photosynthetic area. The most important damage occurs in the fruits, which become commercially depreciated by black-spot lesions and predisposed to postharvest secondary rot (Rezende and Martins, 2005). Losses of $30 \%$ in papaya fruit commercialization have been reported due to black-spot disease (Santos and Barreto, 2003). The control of black-spot is mandatory in commercial crops in order to assure the production of marketable fruits. Periodic spraying with systemic fungicides is the most widely used control measure (Ventura et al., 2003). However, the efficiency of chemical control is complicated by technical and environmental issues, as well as the growing product quality demands of the market, which requires products that are free of chemical residues. In terms of the technical limitations of chemical control, the use of systemic fungicides often comprises the selection of resistant biotypes within pathogenic populations (Ghini, 2001). Thus, genetic resistance has emerged as a promising and sustainable control alternative (Dianese et al., 2007; Vivas et al., 2012b; 2015).

Aiming to select papaya genotypes with black-spot resistance, the current study assessed the behavior of lines derived from the 'Cariflora' genotype, which was converted to hermaphroditism through backcrossing, as well as hybrids from the "top cross" between these lines and four elite testers, in order to estimate their heterotic effect. Such estimates allow hybrids with the lowest black-spot incidence and severity in the leaves and fruits to be identified.

\section{MATERIAL AND METHODS}

The experiment was conducted in the experimental field of Caliman Agrícola S.A, in Linhares City, ES, between 2014 and 2016. According to Köppen's classification, the climate in the region is Awi, a humid tropical climate with a dry winter and maximum rainfall in the summer (Nóbrega et al., 2006).

The experiment comprised 14 lines selected from populations (first and third generations) derived from the backcrossing between the dioiceus genotype 'Cariflora' and the elite variety 'Sunrise Solo 783' (SS 783) (Silva et al., 2007a,b; Ramos et al., 2012; Barros et al., 2017). The hybrids obtained from the crossing between the 14 lines and four SS-72/12 testers (parents of commercial hybrids) belonging to the 'Solo' group, as well as those obtained from the crossing between the 14 lines and JS-12, SEKATI and 41/7 testers belonging to the

Genetics and Molecular Research 16 (1): gmr16019401 
'Formosa' group, were also used in the experiment. Hermaphrodite plants belonging to the lines (pollen donors), and female plants (pollen receptors) derived from elite parents, were used in these crossings. The self-fertilized progenies were obtained by protecting the flowers in order to prevent open pollination.

The experiment encompassed 41 treatments: 14 superior lines, four parents of commercial hybrids, 20 hybrids (SS-72/12 X 1, SS-72/12 X 2, SS-72/12 X 4, SS-72/12 X 6, SS-72/12 X 9, SS-72/12 X 17, SS-72/12 X 19, SEKATI X 1, SEKATI X 2, SEKATI X 4, SEKATI X 6, SEKATI X 9, SEKATI X 10, SEKATI X 17, SEKATI X 20, 41/7 X 10, JS-12 X 1 , JS- 12 X 2, JS- 12 X 17, and JS- 12 X 21), three controls consisting of commercial cultivars ('Golden' and 'Tainung 01'), and one elite line (36/7).

The 41 treatments were sown in December 2014 and transplanted to the field in January 2015. The experiment followed a randomized block design with six repetitions, three plants per plot, totaling 738 plants with spacings of $3.6 \mathrm{~m}$ between rows and $1.5 \mathrm{~m}$ between plants. Three seedlings were planted per hole; however, a single hermaphrodite plant remained after sexing ( 3 months after planting). All plants in each plot of the six blocks were assessed in order to determine mean values per plot.

Three assessments were conducted in August and November 2015 and in March 2016. The severity of black spot in the leaves was estimated through the diagrammatic scale adopted by Vivas et al. (2011), according to the following proportions of injured areas: 0.2, 1.6, 3.5, 5.4, 7.6 , and $12.8 \%$. Black-spot severity was assessed in leaves in which the petiole presented the first newly open inflorescence. Black-spot severity in the fruits was estimated during the fruitripening stage 1, using the diagrammatic scale described by Vivas et al. (2010), according to the following proportions of injured surface area: $0.1,0.3,0.6,1.2,2.5,5.0,10.0$, and $20.0 \%$. The incidence of black-spot in the fruits was calculated by the ratio between the number of fruits showing black-spot symptoms and the total number of fruits in the plant, which was estimated through direct counting.

The cultivation practices in this study followed those adopted in commercial cultivations by Caliman Agricola S.A, through drip irrigation at the base of the plant. In addition to the assessments, chemical management was conducted using herbicide chemical groups such as substituted glycine, bipyridinium, acetanilide, as well as acaricide and insecticide chemical groups such as fatty acid esters, avermectins, and pyrethroids, and fungicide chemical groups such as strobilurins, benzimidazole, triazole, and dithiocarbamate.

Analyses of joint and individual variance were conducted for all variables, by considering the assessment period as the source of variation. The means were grouped through the Scott-Knott test, at 5\% probability. The analyses were performed in the GENES software (Cruz, 2013).

The mean value for each treatment was used to estimate the heterosis and the standard heterosis in each assessed period. The heterosis was calculated through the following equation:

$$
H M P=\left(\frac{M H-M P}{M P}\right) \times 100
$$

where in HMP = percentage of heterosis for the mean of the parents; $\mathrm{MH}=$ mean of the hybrid; $\mathrm{MP}=$ mean of the parents. Conversely, standard heterosis was calculated through the equation:

Genetics and Molecular Research 16 (1): gmr16019401 


$$
H P=\left(\frac{M H-C P}{C P}\right) \times 100
$$

(Equation 2)

where in: $\mathrm{HP}=$ standard cultivar heterosis; $\mathrm{MH}=$ mean of the hybrid; $\mathrm{CP}=$ mean of the standard cultivar.

The control 'Golden' was used to calculate the standard heterosis of the materials belonging to the 'Solo' group, where SS72/12 was one of the parents. The control 'Tainung' was used to calculate the standard heterosis of the materials belonging to the 'Formosa' group, which was derived from crossings using the SEKATI, JS/12, and 41/7 genotypes.

\section{RESULTS AND DISCUSSION}

Black-spot severity in the leaves was highest in August 2015 (Table 1). At that time, the temperature in the experimental area was milder, thus favoring the outbreak.

\begin{tabular}{|c|c|c|c|c|c|c|c|c|}
\hline \multirow[t]{2}{*}{ Crossings and Parents } & \multicolumn{3}{|c|}{ Severity in leaves (\%) } & \multicolumn{2}{|c|}{ Severity in fruits (\%) } & \multicolumn{3}{|c|}{ Incidence in the fruit } \\
\hline & $\mathrm{Aug} / 15$ & Nov/15 & Mar/16 & Aug//15 & Nov/15 & Aug/15 & Nov/15 & $\mathrm{Mar} / 16$ \\
\hline$\overline{\mathrm{L}-1}$ & $0.65 \mathrm{c}^{*}$ & $0.20 \mathrm{a}$ & $0.20 \mathrm{c}$ & $0.01 \mathrm{~b}$ & $0.18 \mathrm{~b}$ & $1.42 \mathrm{~b}$ & $15.78 \mathrm{c}$ & $5.75 \mathrm{~b}$ \\
\hline$\overline{\mathrm{L}-2}$ & $0.34 \mathrm{c}$ & $0.40 \mathrm{a}$ & $0.11 \mathrm{c}$ & $0.00 \mathrm{~b}$ & $1.24 \mathrm{~b}$ & $0.71 \mathrm{~b}$ & $9.30 \mathrm{c}$ & $4.72 \mathrm{~b}$ \\
\hline $\mathrm{L}-4$ & $0.18 \mathrm{c}$ & $0.09 \mathrm{~b}$ & $0.06 \mathrm{c}$ & $0.02 \mathrm{~b}$ & $0.60 \mathrm{~b}$ & $3.04 \mathrm{~b}$ & $12.76 \mathrm{c}$ & $25.80 \mathrm{a}$ \\
\hline $\mathrm{L}-06$ & $1.81 \mathrm{a}$ & $0.24 \mathrm{a}$ & $0.33 \mathrm{~b}$ & $0.28 \mathrm{~b}$ & $4.28 \mathrm{a}$ & $6.84 \mathrm{~b}$ & $11.52 \mathrm{c}$ & $19.80 \mathrm{a}$ \\
\hline $\mathrm{L}-09$ & $0.33 \mathrm{c}$ & $0.05 \mathrm{~b}$ & $0.08 \mathrm{c}$ & $0.01 \mathrm{~b}$ & $0.35 \mathrm{~b}$ & $0.43 \mathrm{~b}$ & $13.24 \mathrm{c}$ & $1.85 \mathrm{~b}$ \\
\hline$\frac{L=03}{L-10}$ & $1.18 \mathrm{~b}$ & $0.11 \mathrm{~b}$ & $0.23 \mathrm{c}$ & $0.08 \mathrm{~b}$ & $0.48 \mathrm{~b}$ & $5.80 \mathrm{~b}$ & $8.24 \mathrm{c}$ & 1.050 \\
\hline$\overline{\mathrm{L}-13}$ & $0.47 \mathrm{c}$ & $0.36 \mathrm{a}$ & $0.25 \mathrm{c}$ & $0.11 \mathrm{~b}$ & $2.13 \mathrm{~b}$ & $2.62 \mathrm{~b}$ & $26.01 \mathrm{~b}$ & $19.57 \mathrm{a}$ \\
\hline $\mathrm{L}-16$ & $0.37 \mathrm{c}$ & $0.17 \mathrm{~b}$ & $0.70 \mathrm{a}$ & $0.30 \mathrm{~b}$ & $0.33 \mathrm{~b}$ & $4.49 \mathrm{~b}$ & $7.66 \mathrm{c}$ & $2.62 \mathrm{~b}$ \\
\hline $\mathrm{L}-17$ & $0.85 \mathrm{~b}$ & $0.09 \mathrm{~b}$ & $0.18 \mathrm{c}$ & $0.01 \mathrm{~b}$ & $0.71 \mathrm{~b}$ & $1.19 \mathrm{~b}$ & $16.30 \mathrm{c}$ & $13.17 \mathrm{a}$ \\
\hline $\mathrm{L}-18$ & $0.22 \mathrm{C}$ & $0.03 \mathrm{~b}$ & $0.08 \mathrm{c}$ & $0.08 \mathrm{~b}$ & $1.11 \mathrm{~b}$ & $7.13 \mathrm{~B}$ & $18.52 \mathrm{c}$ & $3.10 \mathrm{~B}$ \\
\hline $\mathrm{L}-19$ & $0.44 \mathrm{c}$ & $0.06 \mathrm{~b}$ & $0.31 \mathrm{~b}$ & $0.01 \mathrm{~b}$ & $0.24 \mathrm{~b}$ & $0.00 \mathrm{~b}$ & $12.23 \mathrm{c}$ & $4.01 \mathrm{~b}$ \\
\hline $\bar{L}-20$ & $0.31 \mathrm{c}$ & $0.11 \mathrm{~b}$ & $0.06 \mathrm{c}$ & $0.13 \mathrm{~b}$ & $2.41 \mathrm{~b}$ & $5.15 \mathrm{~b}$ & $15.40 \mathrm{c}$ & $10.24 \mathrm{~b}$ \\
\hline $\mathrm{L}-21$ & $0.23 \mathrm{c}$ & $0.07 \mathrm{~b}$ & $0.03 \mathrm{c}$ & $0.44 \mathrm{~b}$ & $5.45 \mathrm{a}$ & $14.59 \mathrm{a}$ & $30.82 \mathrm{a}$ & $9.57 \mathrm{~b}$ \\
\hline $\mathrm{L}-22$ & $0.41 \mathrm{c}$ & $0.10 \mathrm{~b}$ & $0.23 \mathrm{c}$ & $0.13 \mathrm{~b}$ & $2.11 \mathrm{~b}$ & $5.92 \mathrm{~b}$ & $22.73 \mathrm{~b}$ & $11.67 \mathrm{~b}$ \\
\hline$\overline{\mathrm{SS}^{4} \mathrm{X} \mathrm{L}-1}$ & $0.30 \mathrm{c}$ & $0.09 \mathrm{~b}$ & $0.11 \mathrm{c}$ & $0.07 \mathrm{~b}$ & $0.90 \mathrm{~b}$ & $4.09 \mathrm{~b}$ & $9.90 \mathrm{c}$ & $3.73 \mathrm{~b}$ \\
\hline SS X L-2 & $0.28 \mathrm{c}$ & $0.11 \mathrm{~b}$ & $0.13 \mathrm{c}$ & $0.10 \mathrm{~b}$ & $1.37 \mathrm{~b}$ & $5.14 \mathrm{~b}$ & $12.33 \mathrm{c}$ & $5.35 \mathrm{~b}$ \\
\hline SS XL-4 & $0.10 \mathrm{c}$ & $0.05 \mathrm{~b}$ & $0.08 \mathrm{c}$ & $0.04 \mathrm{~b}$ & $0.94 \mathrm{~b}$ & $1.85 \mathrm{~b}$ & $8.05 \mathrm{c}$ & $8.03 \mathrm{~b}$ \\
\hline SSXL-6 & $0.15 \mathrm{c}$ & $0.12 \mathrm{~b}$ & $0.16 \mathrm{c}$ & $0.02 \mathrm{~b}$ & $1.43 \mathrm{~b}$ & $3.38 \mathrm{~b}$ & $15.64 \mathrm{c}$ & $5.04 \mathrm{~b}$ \\
\hline SS XL -9 & $0.04 \mathrm{c}$ & $0.13 \mathrm{~b}$ & $0.07 \mathrm{c}$ & $0.07 \mathrm{~b}$ & $0.30 \mathrm{~b}$ & $3.15 \mathrm{~b}$ & $14.41 \mathrm{c}$ & $3.43 \mathrm{~b}$ \\
\hline SS X L-17 & $0.48 \mathrm{c}$ & $0.18 \mathrm{a}$ & $0.33 \mathrm{~b}$ & $0.05 \mathrm{~b}$ & $1.46 \mathrm{~b}$ & $5.45 \mathrm{~b}$ & $18.65 \mathrm{c}$ & $9.42 \mathrm{~b}$ \\
\hline$\overline{\text { SS X L }-19}$ & $0.12 \mathrm{c}$ & $0.16 \mathrm{~b}$ & $0.08 \mathrm{c}$ & $0.25 \mathrm{~b}$ & $1.81 \mathrm{~b}$ & $4.13 \mathrm{~b}$ & $15.35 \mathrm{c}$ & $0.51 \mathrm{~b}$ \\
\hline SEKATI X L-1 & $0.12 \mathrm{c}$ & $0.21 \mathrm{a}$ & $0.10 \mathrm{c}$ & $0.01 \mathrm{~b}$ & $0.88 \mathrm{~b}$ & $0.86 \mathrm{~b}$ & $11.84 \mathrm{c}$ & $8.96 \mathrm{~b}$ \\
\hline SEKATI X L -2 & $0.12 \mathrm{c}$ & $0.29 \mathrm{a}$ & $0.07 \mathrm{c}$ & $0.00 \mathrm{~b}$ & $1.24 \mathrm{~b}$ & $0.65 \mathrm{~b}$ & $11.96 \mathrm{c}$ & $6.03 \mathrm{~b}$ \\
\hline SEKATI X L -4 & $0.40 \mathrm{c}$ & $0.11 \mathrm{~b}$ & $0.04 \mathrm{c}$ & $0.04 \mathrm{~b}$ & $1.32 \mathrm{~b}$ & $1.99 \mathrm{~b}$ & $16.50 \mathrm{c}$ & $13.39 \mathrm{a}$ \\
\hline SEKATI X L -6 & $0.08 \mathrm{c}$ & $0.16 \mathrm{~b}$ & $0.09 \mathrm{c}$ & $0.04 \mathrm{~b}$ & $4.46 \mathrm{a}$ & $1.38 \mathrm{~b}$ & $18.59 \mathrm{c}$ & $6.67 \mathrm{~b}$ \\
\hline SEKATI X L -9 & $0.36 \mathrm{c}$ & $0.09 \mathrm{~b}$ & $0.08 \mathrm{c}$ & $0.04 \mathrm{~b}$ & $0.45 \mathrm{~b}$ & $1.37 \mathrm{~b}$ & $14.65 \mathrm{c}$ & $2.20 \mathrm{~b}$ \\
\hline SEKATI X L -10 & $0.25 \mathrm{c}$ & $0.10 \mathrm{~b}$ & $0.08 \mathrm{c}$ & $0.29 \mathrm{~b}$ & $3.32 \mathrm{a}$ & $8.73 \mathrm{~b}$ & $19.63 \mathrm{c}$ & $10.02 \mathrm{~b}$ \\
\hline SEKATI X L -17 & $0.09 \mathrm{c}$ & $0.30 \mathrm{a}$ & $0.08 \mathrm{c}$ & $0.22 \mathrm{~b}$ & $1.54 \mathrm{~b}$ & $6.93 \mathrm{~b}$ & $31.95 \mathrm{a}$ & $6.98 \mathrm{~b}$ \\
\hline SEKATI X L -20 & $0.22 \mathrm{c}$ & $0.10 \mathrm{~b}$ & $0.09 \mathrm{c}$ & $0.07 \mathrm{~b}$ & $0.89 \mathrm{~b}$ & $5.59 \mathrm{~b}$ & $18.33 \mathrm{c}$ & $8.91 \mathrm{~b}$ \\
\hline $41 / 7 \times 10$ & $0.12 \mathrm{c}$ & $0.15 \mathrm{~b}$ & $0.10 \mathrm{c}$ & $0.02 \mathrm{~b}$ & $3.48 \mathrm{a}$ & $2.67 \mathrm{~b}$ & $21.53 \mathrm{~b}$ & $17.19 \mathrm{a}$ \\
\hline JS-12X1 & $0.46 \mathrm{c}$ & $0.12 \mathrm{~b}$ & $0.17 \mathrm{c}$ & $0.63 \mathrm{~b}$ & $4.30 \mathrm{a}$ & $7.55 \mathrm{~b}$ & $22.54 \mathrm{~b}$ & $13.64 \mathrm{a}$ \\
\hline $\mathrm{JS}-12 \times 2$ & $0.59 \mathrm{c}$ & $0.18 \mathrm{a}$ & $0.15 \mathrm{c}$ & $5.71 \mathrm{a}$ & $4.85 \mathrm{a}$ & $19.42 \mathrm{a}$ & $24.49 \mathrm{~b}$ & $18.46 \mathrm{a}$ \\
\hline JS-12 X 17 & $0.36 \mathrm{c}$ & $0.22 \mathrm{a}$ & $0.10 \mathrm{c}$ & $1.16 \mathrm{~b}$ & $7.11 \mathrm{a}$ & $6.14 \mathrm{~b}$ & $39.08 \mathrm{a}$ & $8.40 \mathrm{~b}$ \\
\hline $\mathrm{JS}-12 \times 21$ & $0.29 \mathrm{c}$ & $0.09 \mathrm{~b}$ & $0.19 \mathrm{c}$ & $1.18 \mathrm{~b}$ & $6.04 \mathrm{a}$ & $13.81 \mathrm{a}$ & $34.18 \mathrm{a}$ & $10.65 \mathrm{~b}$ \\
\hline $41 / 7$ & $0.08 \mathrm{c}$ & $0.15 \mathrm{~b}$ & $0.13 \mathrm{c}$ & $1.30 \mathrm{~b}$ & $1.32 \mathrm{~b}$ & $9.25 \mathrm{~b}$ & $26.48 \mathrm{~b}$ & $19.01 \mathrm{a}$ \\
\hline SEKATI & $0.13 \mathrm{c}$ & $0.04 \mathrm{~b}$ & $0.12 \mathrm{c}$ & $0.07 \mathrm{~b}$ & $0.55 \mathrm{~b}$ & $4.47 \mathrm{~b}$ & $16.67 \mathrm{c}$ & $4.29 \mathrm{~b}$ \\
\hline JS-12 & $0.20 \mathrm{c}$ & $0.19 \mathrm{a}$ & $0.18 \mathrm{c}$ & $0.13 \mathrm{~b}$ & $0.65 \mathrm{~b}$ & $7.99 \mathrm{~b}$ & $22.87 \mathrm{~b}$ & $10.68 \mathrm{~b}$ \\
\hline$\overline{\mathrm{SS}-72 / 12}$ & $0.54 \mathrm{c}$ & $0.09 \mathrm{~b}$ & $0.05 \mathrm{c}$ & $0.09 \mathrm{~b}$ & $1.38 \mathrm{~b}$ & $1.73 \mathrm{~b}$ & $7.24 \mathrm{c}$ & $1.56 \mathrm{~b}$ \\
\hline $36 / 7$ & $0.06 \mathrm{c}$ & $0.05 \mathrm{~b}$ & $0.03 \mathrm{c}$ & $0.06 \mathrm{~b}$ & $4.53 \mathrm{a}$ & $4.97 \mathrm{~b}$ & $13.57 \mathrm{c}$ & $13.09 \mathrm{a}$ \\
\hline TAINUNG & $0.28 \mathrm{c}$ & $0.06 \mathrm{~b}$ & $0.43 \mathrm{~b}$ & $0.44 \mathrm{~b}$ & $6.06 \mathrm{a}$ & $7.22 \mathrm{~b}$ & $28.96 \mathrm{a}$ & $10.41 \mathrm{~b}$ \\
\hline GOLDEN & $0.22 \mathrm{c}$ & $0.11 \mathrm{~b}$ & $0.11 \mathrm{c}$ & $0.03 \mathrm{~b}$ & $1.63 \mathrm{~b}$ & $1.40 \mathrm{~b}$ & $30.14 a$ & $1.95 \mathrm{~b}$ \\
\hline Mean & 0.35 & 0.14 & 0.15 & 0.33 & 2.09 & 5.02 & 18.19 & 9.31 \\
\hline Amplitude & 1.77 & 0.37 & 0.67 & 5.71 & 6.93 & 18.99 & 31.85 & 25.28 \\
\hline
\end{tabular}

*GroupingofmeansthroughtheScott-Knotttestat5\%probabilitylevel, ineachassessmentperiodandateachassessment location. Means followed by the same letter in columns do not differ at $5 \%$ by the Scott-Knott test. ${ }^{1} \mathrm{SS}=\mathrm{SS} 72 / 12$.

It is assumed that the leaf lesions were derived from infections that had occurred at different times because the fruits stay more time in plant than leaves. This may explain the 
different results observed for black-spot severity between the leaves and fruits. Conversely, black-spot severity was greatest in the fruits in November 2015. The probable lack of fruit infections in August may be related to the fact that this period corresponds to the beginning of fruiting in these genotypes. The highest severity rates in the fruits were found in the subsequent seasons due to the accumulation of infections.

All variables were shown to have a significant effect on all sources of variation tested herein (genotype, assessment season, and genotype-period interaction), which demonstrated the genetic improvement potential of the parents, hybrids, and controls. Each assessment season was individually analyzed in order to determine the importance of each variable to the model, since a significant effect on the genotype-period interaction was observed.

The coefficient of determination $\left(\mathrm{h}^{2}\right)$ presented black-spot rates ranging from 43.17 to $78.15 \%$. Studies have shown that, although the low heritability is not significant, it is possible to achieve successful plant breeding in terms of disease resistance (Vivas et al., 2011, 2014). This is because the differences in the heritability estimates must be interpreted as being specific to the studied genotypes and environments rather than as a fixed attribute of the assessed phenotypic feature (Allard, 1971).

Analyses of individual variance for black-spot severity in the fruits have shown significant genotype effects during the first and second assessment season. As for the analysis of black-spot severity in the leaves and black-spot incidence in the fruits, a significant genotype effect was found during the three assessment periods. It was possible to form three groups in the first and third assessment periods, and two in the second period, when the Scott-Knott (1974) grouping test was applied to black-spot severity in the leaves (Table 1).

The parents showing the lowest means in all assessment periods were from lines 4 , 9, 18, 20, 21, and 22, belonging to genotypes '41/7', 'SEKATI', and 'SS72/12', and to the controls ' $36 / 7$ ' and 'Golden' (Table 1). These results corroborate those reported by Dianese et al. (2007) for SEKATI, highlighting these genotypes as potential parents that may be used to obtain cultivars with increased resistance to black-spot. Additionally, the potential of these parents in hybrid combinations was also assessed.

The following hybrids stood out for black-spot severity in the leaves during the three assessment seasons: SS-72/12 X L-4, SS-72/12 X L-6, SS-72/12 X L-9, SS-72/12 X L-19, SEKATI X L-1, SEKATI X L-6, SEKATI X L-10, SEKATI X L-17, SEKATI X L-20, and 41/7 X L-10 (Table 1). All hybrids had at least one promising parent, with the exception of SS-72/12 X L-6 and SS-72/12 X L-19. Thus, this indicated that such parents may present low severity and help to reduce the disease in crossings. Vivas et al. (2011) selected promising black-spot resistant hybrids in crossings between SEKATI and Sunrise Solo (SS-72/12), which corroborates the results found in the current study. According to the results obtained in the current study, the L-6 and L-9 lines, which were derived from the genotype 'Cariflora', also have breeding potential for disease resistance since their crossings showed the lowest means for disease intensity and incidence (Table 1). This was the first time that hermaphrodite lines derived from dioecious genotypes have been assessed for disease resistance.

The severity rates found in the fruits allowed two groups to be formed in the first and second assessment periods (Table 1). The most resistant parents were the lines 1, 4, 6, 9, 10, $16,17,19,21$, and the elite parents 'SEKATI' and 'JS-12'. Among these parents, genotypes 4, 9, 21, and SEKATI also showed low means for black-spot severity in their leaves, which, in epidemiological terms, is important, since leaf resistance may be associated with fruit resistance or may effectively reduce the inoculum in fruits. Thus, these genotypes may be

Genetics and Molecular Research 16 (1): gmr16019401 
potential parents for of the generation of cultivars with increased resistance to black-spot. The lowest means for black-spot severity in the fruits were observed in the following hybrid combinations: SS-72/12 X L-1, SS-72/12 X L-4, SS-72/12 X L-9, SEKATI X L-1, SEKATI X L-20, and SEKATI X L-9 (Table 1). All of the hybrids, with the exception of SS-72/12 X 1 and SEKATI X 9, were in the most resistant group and showed the lowest means for blackspot severity in their leaves. This demonstrated that the presence of "promising" parents also helped to reduce the disease in the fruit when they were subjected to crossing

The analysis of black-spot incidence in fruits led to the formation of two genotype groups in the first and third assessment seasons and to three groups in the second season (Table 1). As for the incidence of diseased fruits, the best responding lines were 1, 2, 9, 16, and 19, and the genotypes were SEKATI and SS-72/12. With respect to those genotypes, the data concerning black-spot incidence were similar to those obtained for the severity data, confirming that the SEKATI genotype may carry alleles that help to reduce disease in papaya hybrids. The hybrids that showed the best means for diseased fruit incidence were SS-72/12 X 9, SS-72/12 X 19, SEKATI X 1, SEKATI X 2, and SEKATI X 9, which had values lower than those presented by the genotypes from self fecundation. Vivas et al. (2012a) showed that the SEKATI genotype may be a possible source of resistance to black-spot, which corroborates the results of the current study. It is noteworthy that the genotype 'Cariflora' is able to generate hermaphrodite progenies that have potential black-spot resistance, thus generating lines with potential, both individually and in combination, the latter of which allows the heterosis to be explored. Heterosis or hybrid vigor is the phenomenon through which descendants show better performance and increased strength than the average of their parents. Heterosis is most often calculated based on the superior parent (Heterobeltiosis) or on a cultivar of economic importance (standard heterosis) (Allard, 1971; Borém and Miranda, 2009).

Heterosis in the current study was estimated during the assessment periods that showed a significant genotype effect, i.e., the black-spot severity in the leaves, in the three assessment periods; the disease severity in the fruits, in the first and second assessment periods; the disease incidence in the fruits, in the three assessment periods. The combinations presenting negative heterosis estimates for black-spot severity in the leaves, in the three assessment periods, were SS-72/12 X 1 (-50.49; -40.56; -11.80) and SS-72/12 X 6 (-87.22; -29.64; -15.79) (Table 2).

The best hybrids for heterosis concerning reduced black-spot severity in the fruits were SS-72/12 X 4 (-31.42; -5.22), SS-72/12 X 6 (-88.43; -49.44), and SEKATI X 20 (-33.30; -40.22) (Table 2). The negative estimates of heterosis for disease incidence in the fruits were observed in the SS-72/12 X 4 and SEKATI X 9 crossings (Table 2). Of note, the SS-72/12 X 4 and SS-72/12 X 6 hybrids differed from the parents that showed negative heterosis values by taking both fruits and leaves into consideration. The aforementioned hybrids were promising when identifying plants with increased resistance in the leaves and fruits, as well as reduced fruit size, since a genotype from the 'Solo' group was used to cross the lines.

Based on this, heterosis is most often calculated for cultivars of economic importance (standard heterosis). Thus, the current study used the 'Golden' cultivar for the 'Solo' group materials and the 'Tainung' cultivar for the 'Formosa' group materials. According to the calculated heterosis, the SS-72/12 X 4 cross showed negative standard heterosis values for black-spot severity in the leaves, which have demonstrated greater resistance to the most planted 'Solo' group cultivar (Table 3). For the severity of black-spot in the fruits, most 'Formosa' group hybrids showed stronger resistance to the Tainung control, namely: SEKATI X 1, SEKATI X 2, SEKATI X 4, SEKATI X 6, SEKATI X 9, SEKATI X 10, SEKATI X 17 , 
SEKATI X 20, and 41/7 X 10 (Table 3). These data confirmed that the degree of resistance in the parent 'SEKATI' may be passed on to future generations, which generates a good material, both on its own and in crossing.

Table 2. Heterosis estimates for black-spot severity in leaves and fruits, as well as for black-spot incidence, assessed in papaya hybrids derived from crossings with testers from the 'Solo' and 'Formosa' groups, Linhares, Espírito Santo State.

\begin{tabular}{l|c|c|c|c|c|c|c|c}
\hline & \multicolumn{2}{|c|}{ SPPFr $^{1}$} & \multicolumn{2}{c|}{ IPPFr $^{2}$} & \multicolumn{2}{c}{ SPPFo $^{3}$} \\
\hline Hybrids & Aug/15 & Nov/15 & Aug/15 & Nov/15 & Mar/16 & Aug/15 & Nov/15 & Mar/16 \\
\hline SS4 X L-1 & 35.57 & 14.38 & 159.48 & -13.95 & 2.10 & -50.49 & -40.56 & -11.80 \\
\hline SS X L-2 & 122.87 & 4.58 & 321.04 & 49.17 & 70.18 & -36.24 & -55.40 & 68.41 \\
\hline SS X L-4 & -31.42 & -5.22 & -22.37 & -19.49 & -41.30 & -72.29 & -44.44 & 39.45 \\
\hline SS X L-6 & -88.43 & -49.44 & -21.07 & 66.80 & -52.85 & -87.22 & -29.64 & -15.79 \\
\hline SS X L-9 & 40.00 & -65.35 & 191.45 & 40.79 & 101.17 & -90.41 & 85.89 & 2.48 \\
\hline SS X L-17 & 3.41 & 39.49 & 272.87 & 58.46 & 27.85 & -31.41 & 101.76 & 180.07 \\
\hline SS X L-19 & 383.56 & 123.25 & 138.18 & 57.73 & -81.57 & -76.14 & 108.70 & -58.53 \\
\hline SEKATI X L-1 & -87.50 & 139.83 & -70.97 & -27.01 & 78.60 & -70.21 & 73.58 & -38.46 \\
\hline SEKATI X L-2 & -100.00 & 38.23 & -74.76 & -7.92 & 33.85 & 84.38 & 29.85 & -42.00 \\
\hline SEKATI X L-4 & -14.26 & 128.67 & -46.92 & 12.12 & -10.96 & 155.26 & 68.82 & -54.10 \\
\hline SEKATI X L-6 & -76.61 & 84.67 & -75.68 & 31.87 & -44.59 & -91.41 & 13.07 & -59.40 \\
\hline SEKATI X L-9 & 2.21 & 0.37 & -44.18 & -2.03 & -28.42 & 55.21 & 92.67 & -21.95 \\
\hline SEKATI X L-10 & 286.65 & 544.75 & 70.06 & 57.57 & -23.09 & -61.23 & 31.03 & -53.97 \\
\hline SEKATI X L-17 & 466.28 & 142.96 & 144.95 & 93.84 & -20.07 & -82.25 & 358.92 & -49.70 \\
\hline SEKATI X L-20 & -33.30 & -40.22 & 16.21 & 14.31 & 22.66 & -1.12 & 25.33 & 0.94 \\
\hline JS-12 X L-10 & -96.84 & 288.11 & -64.51 & 24.01 & -15.72 & -80.38 & 14.30 & -45.21 \\
\hline JS-12 X L-2 & 833.33 & 937.86 & 60.37 & 16.63 & 66.08 & 6.83 & -39.91 & -10.90 \\
\hline JS-12 X L-17 & 8729.54 & 414.87 & 346.56 & 52.26 & 139.67 & 117.25 & -38.98 & 2.37 \\
\hline JS-12 X L-21 & 1642.99 & 948.38 & 33.73 & 99.55 & -29.56 & -31.95 & 56.82 & -44.69 \\
\hline
\end{tabular}

${ }^{1} \mathrm{SPPFr}=$ black-spot severity in the fruit; ${ }^{2} \mathrm{IPPFr}=$ black-spot incidence in the fruit; ${ }^{3} \mathrm{SPPFo}=$ black-spot severity in the leaf; ${ }^{4} \mathrm{SS}=\mathrm{SS} 72 / 12$.

Table 3. Standard cultivar heterosis for black-spot severity in the leaf and fruit, and black-spot incidence in papaya hybrids derived from crossings with testers from the ‘Solo' and 'Formosa' groups, Linhares, Espírito Santo State.

\begin{tabular}{l|c|c|c|c|c|c|c|c}
\hline \multirow{2}{*}{ Hybrids } & \multicolumn{2}{|c|}{ SPPFr $^{1}$} & \multicolumn{3}{c|}{ IPPFr $^{2}$} & \multicolumn{3}{c}{ SPPFo $^{3}$} \\
\cline { 2 - 9 } & Aug/15 & Nov/15 & Aug/15 & Nov/15 & Mar/16 & Aug/15 & Nov/15 & Mar/16 \\
\hline SS ${ }^{4}$ X L-1 & 122.33 & -44.98 & 192.02 & -67.15 & 91.61 & 35.14 & -23.48 & -1.41 \\
\hline SS X L-2 & 244.33 & -15.78 & 266.70 & -59.09 & 174.57 & 28.26 & -2.91 & 17.65 \\
\hline SS X L-4 & 27.67 & -42.32 & 32.22 & -73.29 & 312.49 & -54.19 & -55.87 & -32.30 \\
\hline SS X L-6 & -27.67 & -12.09 & 141.37 & -48.09 & 158.64 & -31.29 & 3.00 & 41.22 \\
\hline SS X L-9 & 133.33 & -81.56 & 124.73 & -52.18 & 76.20 & -80.90 & 16.24 & -39.72 \\
\hline SS X L-17 & 66.67 & -10.25 & 288.81 & -38.13 & 383.64 & 117.59 & 61.78 & 188.35 \\
\hline SS X L-19 & 733.33 & 11.16 & 194.52 & -49.05 & -73.63 & -46.54 & 39.72 & -33.80 \\
\hline SEKATI X L-1 & -98.87 & -85.41 & -88.15 & -59.11 & -13.96 & -57.82 & 278.73 & -76.74 \\
\hline SEKATI X L-2 & -100.00 & -79.55 & -90.95 & -58.72 & -42.11 & 56.60 & 421.27 & -84.49 \\
\hline SEKATI X L-4 & -90.94 & -78.25 & -72.38 & -43.02 & 28.64 & 44.56 & 96.91 & -90.30 \\
\hline SEKATI X L-6 & -90.56 & -26.37 & -80.95 & -35.81 & -35.91 & -69.90 & 187.82 & -78.67 \\
\hline SEKATI X L-9 & -90.56 & -92.51 & -81.06 & -49.42 & -78.91 & 29.49 & 57.64 & -81.40 \\
\hline SEKATI X L-10 & -35.09 & -45.25 & 20.92 & -32.22 & -3.75 & -8.46 & 72.73 & -81.00 \\
\hline SEKATI X L-17 & -49.81 & -74.62 & -3.97 & 10.34 & -33.00 & -68.67 & 442.36 & -82.16 \\
\hline SEKATI X L-20 & -84.90 & -85.36 & -22.59 & -36.71 & -14.46 & -20.49 & 72.73 & -78.67 \\
\hline 41/7 X L-10 & -95.09 & -42.53 & -63.00 & -25.66 & 65.08 & -55.44 & 166.73 & -76.74 \\
\hline JS-12 X L-1 & 42.63 & -29.01 & 4.57 & -22.18 & 31.04 & 65.05 & 112.18 & -60.47 \\
\hline JS-12 X L-2 & 1192.35 & -19.93 & 169.12 & -15.44 & 77.31 & 112.61 & 227.27 & -65.88 \\
\hline JS-12 X L-17 & 163.01 & 17.45 & -14.94 & 34.95 & -19.31 & 28.91 & 296.91 & -76.74 \\
\hline JS-12 X L-21 & 167.90 & -0.22 & 91.34 & 18.03 & 2.26 & 4.19 & 60.55 & -55.42 \\
\hline
\end{tabular}

${ }^{1} \mathrm{SPPFr}=$ black-spot severity in the fruit; ${ }^{2} \mathrm{IPPFr}=$ black-spot incidence in the fruit; ${ }^{3} \mathrm{SPPFo}=$ black-spot severity in the leaf; ${ }^{4} \mathrm{SS}=\mathrm{SS} 72 / 12$.

Genetics and Molecular Research 16 (1): gmr16019401 
Only the SS-72/12 X 6 crossing was superior to the standard 'Golden' cultivar in all assessments, when the 'Solo' group was assessed for black-spot severity in the fruits (Table 3). This result was also found for the heterosis related to the average of the parents, and it demonstrated the resistance of this material to the detriment of the control.

In terms of the incidence of black-spot in the fruits, only the hybrids from the 'Formosa' group (SEKATI X 1', 'SEKATI X 2', 'SEKATI X 6', 'SEKATI X 9', and 'SEKATI X 20') showed increased resistance to the cultivar 'Tainung', in all assessment periods. Thus, this confirms the superiority of these hybrids over the standard controls used in the current study.

The 'Solo' group hybrid 'SS-72/12 X 4' showed lower black-spot severity and incidence rates in its fruits, and the 'Formosa' group hybrids 'SEKATI X 1', 'SEKATI X 2', 'SEKATI X 6', 'SEKATI X 9', and 'SEKATI X 20' showed good black-spot severity and incidence estimates in the fruits when all the variables were considered. These also had the lowest levels of black-spot severity and incidence in all assessment periods (Table 1), which indicates that crossings aiming to produce hybrid papaya seeds can show genetic superiority and resistance to diseases.

Using the materials utilized in the current study, lines 2 and 9 were found to be promising for both fruit production and quality (Santa Catarina, 2016). This fact integrates disease resistance, since both lines showed the lowest mean values for blackspot incidence in the fruits. Line 9 stood out as promising when the severity of black-spot was assessed in both the leaves and the fruits.

Santa Catarina (2016) assessed the agronomic features of the 'Solo' group and presented the following hybrids: SS-72/12 X 1, SS-72/12 X 2, SS-72/12 X 6, and SS$72 / 12 \times 9$. With respect to resistance, the results of the current study showed that the SS-72/12 X 1 and SS-72/12 X 9 hybrids presented low means for black-spot severity in the fruits, and that crosses involving line 9 presented low means for black-spot severity in the leaves and incidence in the fruits. The 'Formosa' hybrids 'Sekati X 2', 'Sekati X 4', 'Sekati X 6', and 'Sekati X 10' have shown superior agronomic features and fruit quality. The 'Sekati X 2' hybrid has shown the lowest means for black-spot severity and incidence in the fruits. The 'Sekati X 4' hybrid has shown the lowest mean for black-spot severity in the leaves and fruits, and the 'Sekati X 6' and 'Sekati X 10' hybrids have shown the lowest means for black-spot severity in the leaves and incidence in the fruits.

The SS-72/12 X 1 and SS-72/12 X 9 hybrids from the 'Solo' group, as well as the Sekati X 2, Sekati X 4, Sekati X 6, and Sekati X 10 hybrids from the 'Formosa' group, showed the greatest resistance to pathogen attack, which was consistent with the study conducted by Santa Catarina (2016) on agronomic and fruit quality features. This study suggested that it is worth selecting these hybrids to perform new competition tests in different environments, aiming for the future release of agronomically superior and blackspot resistant hybrids of the papaya 'Solo' group.

In conclusion, the genotypes showing the greatest resistance to black-spot were lines 1, 4, 9, and 19. Lines 4 and 9, and the parent 'SEKATI' generated the best results in all the variables assessed herein. The SS-72/12 x 4, SS-72/12 x 6, SEKATI x 1, SEKATI x 2 , SEKATI x 6, SEKATI x 9, and SEKATI x 20 hybrids were notable for the magnitude of the heterosis estimates concerning both the mean of the parents and the commercial varieties in order to reduce black-spot intensity in papaya cultivars from both the 'Solo' and the 'Formosa' groups.

Genetics and Molecular Research 16 (1): gmr16019401 


\section{Conflicts of interest}

The authors declare no conflict of interest.

\section{ACKNOWLEDGMENTS}

The authors thank Caliman Agrícola Company S/A, for their support. We acknowledge Coordenação de Aperfeiçoamento de Pessoal de Nível Superior (Capes), Fundação Carlos Chagas Filho de Amparo à Pesquisa do Estado do Rio de Janeiro (FAPERJ), and Universidade Estadual do Norte Fluminense Darcy Ribeiro, for financing and supporting this research.

\section{REFERENCES}

Allard RW (1971). Princípios do melhoramento genético de plantas. 2nd edn. Edgar Blucher, São Paulo.

Barros GBA, Aredes FAS, Ramos HCC, Santa Catarina R, et al. (2017). Combining ability of recombinant lines of papaya from backcrossing for sexual conversion. Rev. Cienc. Agron. 48: 166-174.

Borém A and Miranda GV (2009) Melhoramento de Plantas. 5th edn. Viçosa, MG, UFV.

Cruz CD (2013). GENES a software package for analysis in experimental statistics and quantitative genetics. Acta Sci. 35: $271-276$.

Dianese AC, Blum LEB, Dutra JB, Lopes LF, et al. (2007). Reação de Genótipos de Mamoeiro à Varíola e à Podridão-dopé. Fitopatol. Bras. 32: 419-423. http://dx.doi.org/10.1590/S0100-41582007000500008

Ghini R (2001). Fungos resistentes. Revista Cultivar Grandes Culturas 28 [http://www.grupocultivar.com.br/artigos/ fungos-resistentes] Accessed July 12, 2016.

Hafsah S, Sastrosumarjo S, Sujiprihati S, Sobir S, et al. (2007). Daya Gabung dan Heterosis Ketahanan Pepaya (Carica papaya L.) terhadap Penyakit Antraknosa. Bul. Agron. 35.

IBGE (2014). Instituto Brasileiro de Geografia e Estatística. Available at [http://www.ibge.gov.br/home/]. Accessed July 17, 2016.

Marin SLD, Pereria MG, Amaral Jr AT, Marteletto LAP, et al. (2006). Partial diallel to evaluate the combining ability for economically important traits of papaya. Sci. Agric. 6: 540-546.

Nóbrega NEF, Silva JGF, Ramos HDA and Pagung FDS (2006). Balanço hídrico climatológico e classificação climática de Thornthwaite e Köppen para o município de Linhares-ES. Hidrometerologia Incaper [http//www. hidrometeorologia. incaper.es.gov.br/arquivos_pdf/publicacoes/]. Accessed July 2, 2016.

Ramos HCC, Pereira MG, Gonçalves LSA, Berilli APCG, et al. (2012). Multivariate analysis to determine the genetic distance among backcross papaya (Carica papaya) progenies. Genet. Mol. Res. 11: 1280-1295. http://dx.doi. org/10.4238/2012.May.14.2

Reetz ER, Kist BB, Santos CE, Carvalho C, et al. (2015). Anuário brasileiro da Fruticultura 2014. Santa Cruz do Sul: Ed. Gazeta Santa Cruz.

Rezende JAM and Martins MC (2005). Doenças do Mamoeiro (Carica papaya). Capitulo 49 do Livro Manual de Fitopatologia. Doença das Plantas Cultivadas 2, São Paulo, 435-443.

Santa Catarina R (2016). Capacidade combinatória, heterose de linhagens endogâmicas recombinantes e análise de imagens digitais em mamoeiro (Carica papaya L.). Dissertação de Mestrado, Universidade Estadual do Norte Fluminense Darcy Ribeiro, Campos dos Goytacazes, 86. Available at [http://uenf.br/posgraduacao/gmp/wp-content/ uploads/sites/6/2016/02/Tese-MS-Renato-Santa-Catarina.pdf]. Accessed December 3, 2016.

Santos MC and Barreto M (2003). Estudo epidemiológico da varíola do mamoeiro em cultivares submetidas a tratamentos com fungicidas. Summa Phytopathol. Botucatu 29: 141-146.

Silva FF, Pereira MG, Campos WF, Damasceno Júnior PC, et al. (2007a). DNA marker-assisted sex conversion in elite papaya genotype (Carica papaya L.). Crop Breed. Appl. Biotechnol. 7: 52-58. http://dx.doi.org/10.12702/1984-7033.v07n01a08

Silva FF, Pereira MG, Damasceno Júnior PC, Pereira TNS, et al. (2007b). Evaluation of the sexual expression in segregation BC1 papaya population. Crop Breed. Appl. Biotechnol. 7: 16-23. http://dx.doi.org/10.12702/1984-7033.v07n01a03

Ventura JA, Costa H and Tatagiba JS (2003). Manejo das doenças do mamoeiro. In: Cultura do mamoeiro: tecnologias de produção (Martins DS and Costa AFS, eds.), 229-308.

Vivas M, Terra CEPS, Silveira SF, Fontes RV, et al. (2010). Diagrammatic scale for assessing severity of back-spot in papaya fruit. Summa Phytopathol. 36: 161-163. http://dx.doi.org/10.1590/S0100-54052010000200010

Genetics and Molecular Research 16 (1): gmr16019401 
Vivas M, Silveira SF, Terra CEPS and Pereira MG (2011). Testers for combining ability and selection of papaya hybrids resistant to fungal diseases. Crop Breed. Appl. Biotechnol. 11: 36-42. http://dx.doi.org/10.1590/S198470332011000100005

Vivas M, Silveira SF, Vivas JMS and Pereira MG (2012a). Patometria, parâmetros genéticos e reação de progênies de mamoeiro à Pinta-preta. Bragantia 71: 235-238. http://dx.doi.org/10.1590/S0006-87052012005000021

Vivas M, Silveira SF, Cardoso DL, Pereira MG, et al. (2012b). Capacidade combinatória e heterose para resistência a pinta preta em mamoeiro por meio de análise dialélica. Trop. Plant Pathol. 37: 326-332. http://dx.doi.org/10.1590/ $\underline{\text { S1982-56762012000500004 }}$

Vivas M, Silveira SF, Viana AP, Amaral Jr AT, et al. (2014). Efficiency of circulant diallels via mixed models in the selection of papaya genotypes resistant to foliar fungal diseases. Genet. Mol. Res. 13: 4797-4804. http://dx.doi. org/10.4238/2014.July.2.9

Vivas M, Silveira SF, Viana AP, Amaral Jr AT, et al. (2015). Resistance to multiple foliar diseases in papaya genotypes in Brazil. Crop Prot. 71: 138-143. http://dx.doi.org/10.1016/j.cropro.2015.02.007 